\title{
Distribution of CFTR mutations in Saguenay- Lac-Saint-Jean: proposal of a panel of mutations for population screening
}

Anne-Marie Madore, MSc ${ }^{1,2,3}$, Claude Prévost, MSc ${ }^{4}$, Ruslan Dorfman, PhD ${ }^{5}$, Chelsea Taylor, MSc ${ }^{5}$, Peter Durie, $M D, F R C P^{5}$, Julian Zielenski, $P h D^{5}$, and Catherine Laprise, $P h D^{2,3}$

\begin{abstract}
Purpose: Saguenay-Lac-Saint-Jean is a region located in the northeastern part of the Province of Quebec, Canada, and is characterized by a founder effect. In this region, it has been documented that the incidence of cystic fibrosis reached 1/902 live births between 1975 and 1988, three times higher than the average incidence of 1/2500 live births reported in other Caucasian populations. This corresponds to a carrier rate of $1 / 15$. Methods: Using genotyping data from the Canadian Consortium for Cystic Fibrosis Genetic Studies, this article describes the cystic fibrosis transmembrane conductance regulator profile of the cystic fibrosis population living in the Saguenay-LacSaint-Jean region and compares it with cystic fibrosis populations living in three other regions of the Province of Quebec. Results: Significant differences in allelic frequencies of common mutations (as $\triangle F 508,621+1 G>T$ and $\mathrm{A} 455 \mathrm{E}$ ), and in percentage of covered allele with three or six mutations, were found in Saguenay-Lac-Saint-Jean compared to other regions. Based on this result, two mutation panels exceeding $90 \%$ sensitivity threshold are now proposed for cystic fibrosis carrier screening in this region. Conclusion: The implementation of the proposed carrier screening program could diminish the incidence of this disease in this region and allow future parents to make informed decisions about family planning. Genet Med 2008:10(3):201-206.
\end{abstract}

Key Words: Cystic fibrosis, Saguenay-Lac-Saint-Jean, carrier screening, mutations, CFTR

The Quebec population numbers more than seven million, of which roughly six million have descended from French settlers. Among the 25,000 settlers who came from various provinces of France between the beginning of the 17th century and the British conquest of 1763 , only about 8,500 , including 1,600 women, settled permanently. ${ }^{1-3}$ It was demonstrated that the 2,600 settlers established in "Nouvelle-France" before 1680 contributed about two thirds of the gene pool of the current Francophone population. ${ }^{1,4}$ A mosaic of founder effects was observed in rural regions recently opened to colonization and, while inter-regional migrations have increased with time, regional genetic variation persists throughout the Province of Quebec (PQ). The Saguenay-Lac-Saint-Jean (SLSJ) region is a well-documented example of this phenomenon. ${ }^{5}$ It is a geographically isolated region located in the northeastern part of Quebec. Several studies have demonstrated an increased inci-

\footnotetext{
From the ${ }^{1}$ Université Laval, Québec, Canada; ${ }^{2}$ Université de Montréal Community Genomic Medicine Center, Saguenay, Canada; ${ }^{3}$ Université du Québec à Chicoutimi, Saguenay, Canada; ${ }^{4}$ Service de conseil génétique, Centre de santé et de services sociaux de Chicoutimi, Saguenay, Canada; and ${ }^{5}$ Hospital for Sick Children, Toronto, Canada.

Catherine Laprise, PhD, Université du Québec à Chicoutimi, 555 blvd de l'Université, Chicoutimi (Québec), Canada G7H 2B1.E-mail: catherine_laprise@uqac.ca.

Disclosure: The authors declare no conflict of interest.

Submitted for publication October 10, 2007.

Accepted for publication December 1, 2007.

DOI: $10.1097 /$ GIM.0b013e318164cb1c
}

dence of autosomal dominant and recessive disorders in this region. ${ }^{6,7}$ In SLSJ, it was documented that the incidence of cystic fibrosis (CF) reached 1 live birth per 902 between 1975 and 1988, which corresponds to a carrier rate of $1 / 15 .^{8,9}$ This is three times higher than the average incidence of $1 / 2500$ live births in other Caucasian populations (or a carrier rate of 1/25).

$\mathrm{CF}$ is a multisystemic disorder caused by mutations in the $\mathrm{CF}$ transmembrane conductance regulator $(C F T R)$ gene. ${ }^{10} \mathrm{It}$ affects both the respiratory and the digestive systems, and can also induce infertility in men. ${ }^{11} \mathrm{~A}$ variable genetic correlation was observed between CFTR mutations and pulmonary function, ${ }^{12}$ pancreatic insufficiency, ${ }^{13}$ and congenital bilateral absence of the vas deferens. ${ }^{14}$ This subject is reviewed at length in a recent review by Dorfman and Zielenski. ${ }^{15}$ Since it was cloned in 1989, over 1,500 CFTR mutations have been documented. ${ }^{16,17}$ Some of them, such as $\triangle F 508$, are commonly distributed, whereas others are found in specific populations or ethnic groups, such as the $M 1101 \mathrm{~K}$ in Hutterites. ${ }^{18,19}$ The protein encoded by the CFTR gene is expressed in the apical membrane of exocrine epithelial cells, and is a cyclic adenosine monophosphate (cAMP)-induced chloride channel that can also regulate other ion channels. ${ }^{10,20}$

For CF neonatal screening, many programs throughout the world have adopted a two-tier combination of trypsinogen and DNA analysis with either $\triangle F 508$ allele alone or a panel of CFcausing mutations. ${ }^{21}$ In the same way, multimutation plat- 
forms can be built to offer carrier screening in different populations. To do so, there is a need to determine which mutations should be part of a CFTR mutation screening panel to reach a high sensitivity $(>90 \%)$ in a particular population..$^{22}$ In this report, after having assessed and compared the distribution of CFTR mutations in the SLSJ region with that of three other regions of $\mathrm{PQ}$, we propose a mutation panel for carrier screening purposes in the SLSJ population.

\section{MATERIALS AND METHODS}

\section{Subjects}

The Canadian Consortium for Cystic Fibrosis Genetic Studies has genotyped samples from 6 of the 10 different CF clinics of the PQ, totaling 482 patients with CF (Canadian Consortium for Cystic Fibrosis Genetic Studies, unpublished data). It represents $45 \%$ of the patients with CF living in the PQ. All patients have an established diagnosis of CF. The phenotypic description of these patients, including sex ratio, mean age, percent predicted value of forced expiratory volume in one second $\left(\mathrm{FEV}_{1}\right)$, and body mass index (BMI), is shown in Table 1. The project was approved by the ethics committee of the Hospital for Sick Children and informed consent was obtained from all subjects. In this study, we grouped the samples of the six clinics into four populations (see Fig. 1). The first population is from the SLSJ region, and is mainly composed of Francophones (Centre de santé et de services sociaux de Chicoutimi; $n=85$ ). The second population, also mainly composed of Francophones, is from Sherbrooke (Centre hospitalier universitaire de Sherbrooke; $n=42$ ), a city located southeast of Montreal and close to the United States border. Montreal is the largest city of the PQ and the most ethnically diversified. It is composed of individuals (Francophones and

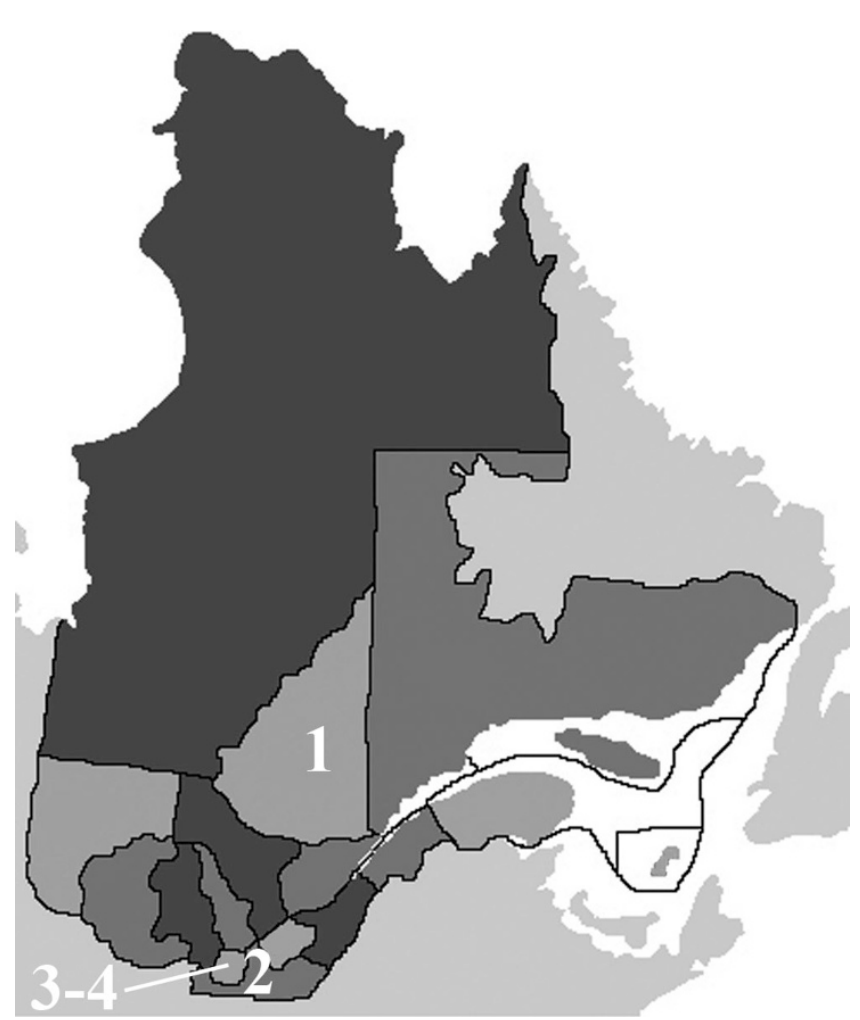

Fig. 1. Map of the Province of Quebec. The different regions of the Province of Quebec. The numbers one, two, three, and four represent the Saguenay-Lac-Saint-Jean region (Chicoutimi CF clinic), the Sherbrooke CF clinic, the Montreal Francophone CF clinics, and the Montreal Anglophone and multiethnic CF clinics, respectively.

Anglophones) who have been living there for many generations, individuals (mostly Francophone) coming from all other regions of the $\mathrm{PQ}$, and immigrants (multiethnics). Samples from the four CF clinics in Montreal were grouped into

Table 1

Phenotypic description of the subjects

\begin{tabular}{|c|c|c|c|c|c|c|}
\hline \multirow[b]{3}{*}{ Institution $^{b}$} & \multicolumn{6}{|c|}{ Population $^{a}$} \\
\hline & \multirow{2}{*}{ 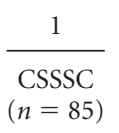 } & \multirow{2}{*}{$\begin{array}{c}2 \\
\text { CHUS } \\
(n=42)\end{array}$} & \multicolumn{2}{|c|}{3} & \multicolumn{2}{|c|}{4} \\
\hline & & & $\begin{array}{c}\text { CHUM } \\
(n=196)\end{array}$ & $\begin{array}{l}\text { CHUSJ } \\
(n=96)\end{array}$ & $\begin{array}{c}\mathrm{MCH} \\
(n=53)\end{array}$ & $\begin{array}{c}\text { MCI } \\
(n=10)\end{array}$ \\
\hline \multicolumn{7}{|l|}{ Children } \\
\hline Mean age (yr) & 12 & 10 & NA & 10 & 9 & NA \\
\hline Mean $\mathrm{FEV}_{1}(\%$ pred $)$ & 85.56 & 83.30 & NA & 89.25 & 70.5 & NA \\
\hline Mean BMI $\left(\mathrm{kg} / \mathrm{m}^{2}\right)$ & 17.17 & 17.28 & NA & 17.65 & 16.75 & $\mathrm{NA}$ \\
\hline \multicolumn{7}{|l|}{ Adults } \\
\hline Mean age (yr) & 29 & 27 & 27 & NA & NA & 32 \\
\hline Mean $\mathrm{FEV}_{1}(\%$ pred $)$ & 52.74 & 54.79 & 61.27 & NA & NA & 43.21 \\
\hline Mean BMI $\left(\mathrm{kg} / \mathrm{m}^{2}\right)$ & 21.93 & 21.19 & 21.77 & NA & NA & 21.27 \\
\hline
\end{tabular}

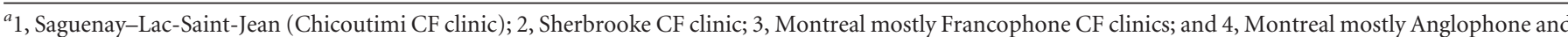
multi-ethnic CF clinics.

${ }^{b}$ CSSSC, Centre de santé et de services sociaux de Chicoutimi; CHUS, Centre hospitalier universitaire de Sherbrooke; CHUM, Centre hospitalier de l’Université de Montréal; CHUSJ, Centre hospitalier universitaire Sainte-Justine; MCH, Montreal Children's Hospital; MCI, Montreal Chest Institute.

$\mathrm{NA}$, not available; $\mathrm{FEV}_{1}$, (\% pred), forced expiratory volume in one second (\% predicted value); BMI, body mass index. 
Mutation panel for CFTR screening in SLSJ

two populations: the third and the fourth populations of this study; one is mostly composed of Francophones (Centre hospitalier de l'Université de Montréal and Centre hospitalier universitaire Sainte-Justine; $n=292$ ) and the other is mostly composed of Anglophones and immigrants (Montreal Children's Hospital and Montreal Chest Institute; $n=63$ ).

\section{CFTR mutation screening}

The CFTR genotyping was performed using two methods: multiplexed heteroduplex analysis ${ }^{23}$ and high-resolution melt analysis with SYTO9 (Invitrogen, Burlington, Canada) and Corbett Rotor-Gene 6000HRM (Corbett Life Science, Sydney, Australia) instrument ${ }^{24}$ followed by resequencing of the identified fragments. Large deletion detection was performed using established conditions. ${ }^{25,26}$ Some samples with incomplete CFTR genotype $(n=128)$ were screened for large deletions by Quest Diagnostics (Madison, NJ).27,28

\section{Statistical analysis}

A $\chi^{2}$ test was used to make comparisons between the allele distributions of the different populations, a $P$-value $<0.05$ was considered significant.

\section{RESULTS}

Data from the Canadian Consortium for Cystic Fibrosis Genetic Studies make it possible to describe the distribution of CFTR mutations in the SLSJ region and to compare it with that of three other regions in the PQ (see Table 2 for allelic frequencies). Three mutations are prevalent in the SLSJ population $(\triangle \mathrm{F} 508,621+1 \mathrm{G}>\mathrm{T}$, and $\mathrm{A} 455 \mathrm{E})$; according to data provided by the genetic counseling services and the Chicoutimi $\mathrm{CF}$ clinic, three other mutations are present in at least three different families $(711+1 \mathrm{G}>\mathrm{T}$, 3199del6, and Y1092X). Figure 2 illustrates the differences in the distribution of these six mutations in the SLSJ region compared with the three other regions. Although the $\triangle \mathrm{F} 508$ and $621+1 \mathrm{G}>\mathrm{T}$ mutations are more frequent in all populations studied, their distribution in the SLSJ region is different. The mutation $\triangle \mathrm{F} 508$ is less represented in the SLSJ (Fig. 2, A) population than in the other French populations studied $(P=0.011)$ (Fig. 2, B and $C$ ). Moreover, the $621+1 \mathrm{G}>\mathrm{T}$ is three to four times more frequent in the SLSJ population than in the two other Francophone population described here $\left(P<10^{-12}\right)$ and more than 25 times more frequent than in the Anglophone and multiethnic population of Montreal $\left(P<10^{-7}\right)$ (Fig. 2, D). Similarly, the $\mathrm{A} 455 \mathrm{E}$ mutation frequency is two to three times higher in the SLSJ population compared with the other Francophone population studied $(P=0.004)$ and eight times higher than in the Anglophone and multiethnic population of Montreal $(P=$ 0.013). Moreover, there is only one unknown CF allele in the SLSJ population compared with 25 only in the Francophone populations $(P=0.027)$ and also 25 in the Anglophone and multiethnic population $\left(P<10^{-8}\right)$. Altogether, the six mutations represent $95.89 \%$ of the CFTR allele of CF patients in the SLSJ population, whereas the proportions are $86.85,85.27$, and
Table 2

Cystic fibrosis mutations present in the four populations studied

\begin{tabular}{|c|c|c|c|c|}
\hline \multirow[b]{2}{*}{ Mutation $^{a}$} & \multicolumn{4}{|c|}{$\begin{array}{l}\text { Allelic frequency (number of alleles [\%]) } \\
\text { Population }{ }^{b}\end{array}$} \\
\hline & 1 & 2 & 3 & 4 \\
\hline$\Delta \mathrm{F} 508$ & $106(62.35)$ & $55(72.37)$ & $398(72.36)$ & $67(57.78)$ \\
\hline $621+1 G>T$ & $42(24.71)$ & $6(7.89)$ & $30(5.45)$ & $1(0.85)$ \\
\hline A455E & $12(7.06)$ & $2(2.63)$ & $14(2.55)$ & $1(0.85)$ \\
\hline 3199del6 & $1(0.59)$ & $1(1.32)$ & $7(1.27)$ & $1(0.85)$ \\
\hline $711+1 G>T$ & $1(0.59)$ & $1(1.32)$ & $15(2.73)$ & $1(0.85)$ \\
\hline Y1092X & $1(0.59)$ & $1(1.32)$ & $5(0.91)$ & 0 \\
\hline R117C & $2(1.18)$ & 0 & 0 & 0 \\
\hline$\triangle \mathrm{I} 507$ & $1(0.59)$ & $2(2.63)$ & $10(1.82)$ & 0 \\
\hline L206W & $1(0.59)$ & $1(1.32)$ & $9(1.64)$ & 0 \\
\hline R1158X & $1(0.59)$ & 0 & 0 & 0 \\
\hline S489X & $1(0.59)$ & 0 & $1(0.18)$ & 0 \\
\hline R553X & 0 & $2(2.63)$ & $2(0.36)$ & 0 \\
\hline R334W & 0 & $1(1.32)$ & $2(0.36)$ & 0 \\
\hline G542X & 0 & 0 & $10(1.82)$ & 0 \\
\hline G85E & 0 & 0 & $6(1.09)$ & $5(4.24)$ \\
\hline N1303K & 0 & 0 & $5(0.91)$ & $1(0.85)$ \\
\hline IVS8-5T & 0 & 0 & $4(0.73)$ & 0 \\
\hline W1282X & 0 & 0 & $3(0.55)$ & $7(5.93)$ \\
\hline R347P & 0 & 0 & $1(0.18)$ & $2(1.69)$ \\
\hline V520F & 0 & 0 & $1(0.18)$ & 0 \\
\hline $\mathrm{I} 1027 \mathrm{~T}$ & 0 & 0 & $1(0.18)$ & 0 \\
\hline R1066C/IVS & 0 & 0 & $1(0.18)$ & 0 \\
\hline Q1313X & 0 & 0 & $1(0.18)$ & 0 \\
\hline $1898+3 \mathrm{G}>\mathrm{A}$ & 0 & 0 & $1(0.18)$ & 0 \\
\hline $2183 \mathrm{AA}>\mathrm{G}$ & 0 & 0 & $1(0.18)$ & 0 \\
\hline 2951insA & 0 & 0 & $1(0.18)$ & 0 \\
\hline G551D & 0 & 0 & 0 & $2(1.69)$ \\
\hline 1525-iG-A & 0 & 0 & 0 & $2(1.69)$ \\
\hline Y109C & 0 & 0 & 0 & $1(0.85)$ \\
\hline S549N & 0 & 0 & 0 & $1(0.85)$ \\
\hline 3154del1G & 0 & 0 & 0 & $1(0.85)$ \\
\hline UNKNOWN & $1(0.59)$ & $4(5.26)$ & $20(3.82)$ & $25(21.19)$ \\
\hline $\begin{array}{l}\text { Number of alleles } \\
\text { genotyped }^{c}\end{array}$ & $170(100)$ & $76(100)$ & $550(100)$ & $118(100)$ \\
\hline
\end{tabular}

${ }^{a}$ The six mutations included in the panels proposed are in bold.

${ }^{b} 1$, Saguenay-Lac-Saint-Jean (Chicoutimi CF clinic); 2, Sherbrooke CF clinic; 3, Montreal mostly Francophone CF clinics; 4, Montreal mostly Anglophone and multi-ethnic CF clinics.

${ }^{c}$ For each population, some alleles could not be genotyped (mean call rate for population 1: $100 \%$; population 2: $90.48 \%$; population 3: $94.18 \%$; population 4: $93.65 \%)$. 
A)
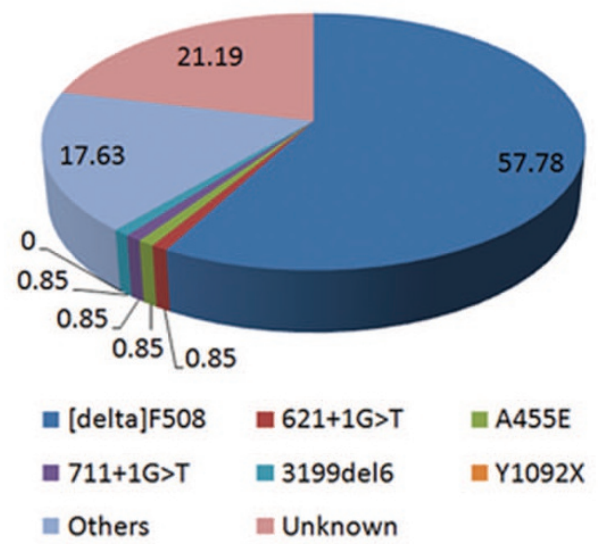

C)
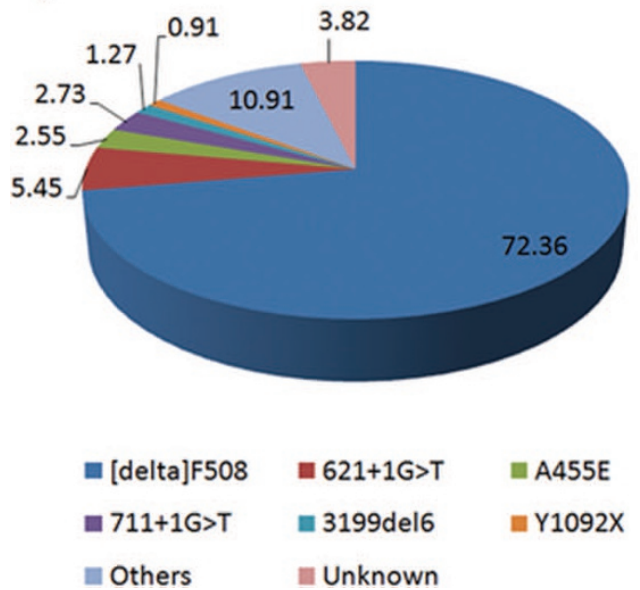

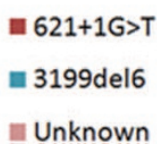

A455E

밀 $1092 \mathrm{X}$
B)

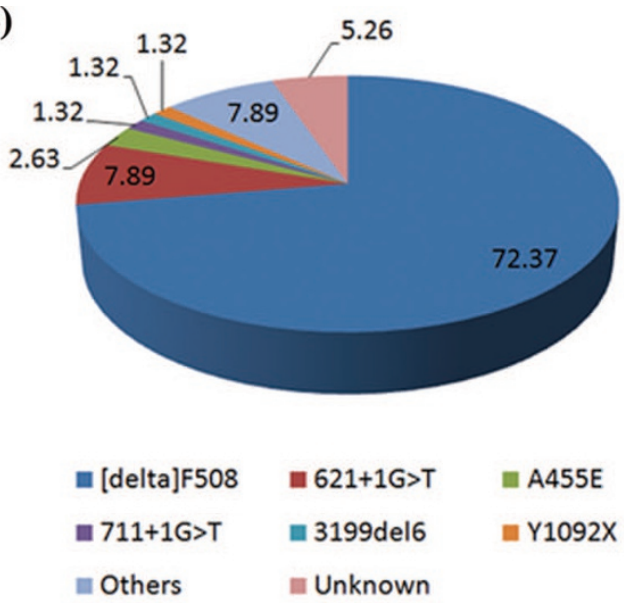

D)

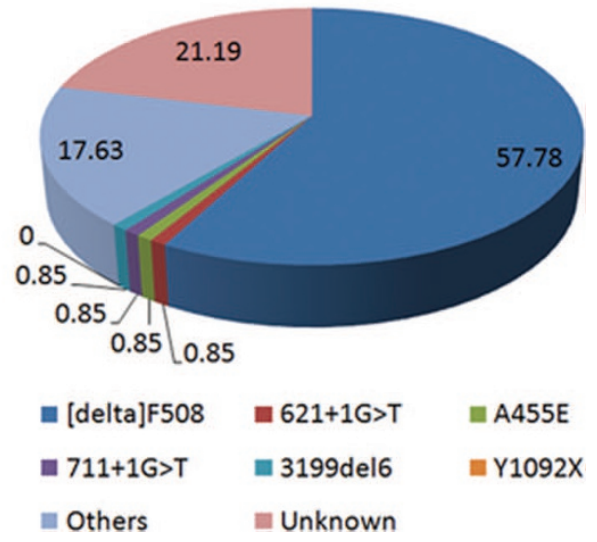

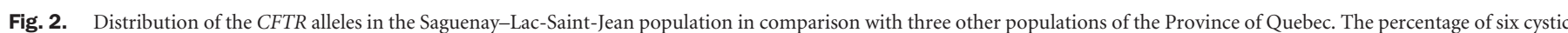

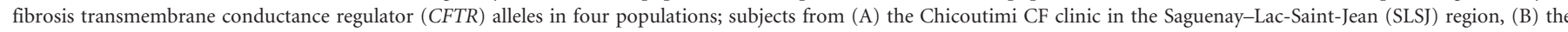

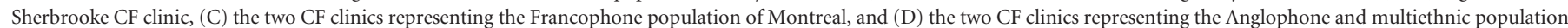

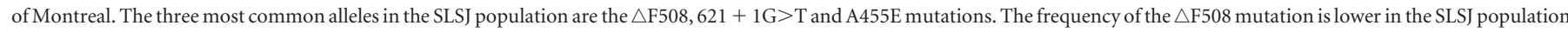

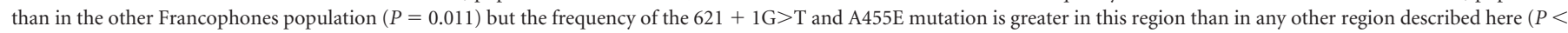

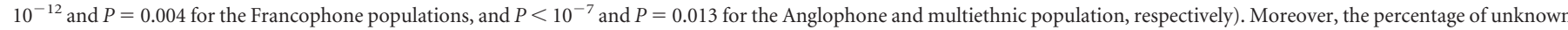

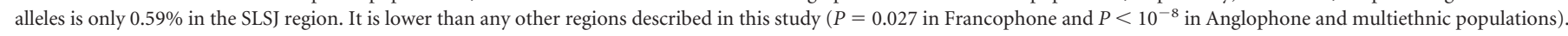

61.18\% for the Sherbrooke CF clinic, the Montreal Francophone $\mathrm{CF}$ clinics, and the Montreal Anglophone and multiethnic CF clinics, respectively $\left(P=0.010, P<10^{-3}\right.$, and $P<10^{-13}$, respectively) (Figs. 2 and 3 ).

\section{DISCUSSION}

Bobadilla et al. ${ }^{21}$ proposed a 50 -mutation platform for CF neonatal diagnosis, considering the most prevalent mutations and those that are present in different ethnic subgroups in the US population. Previously, the American College of Medical Genetics (ACMG) and the American College of Obstetricians and Gynecologists (ACOG), in conjunction with the National Human Genome Research Institute, have also proposed a panel for CF screening in the US population comprising 23 mutations. ${ }^{29,30}$ Those examples illustrate the great challenge encountered when building a multimutation screening pro- gram for CF disease in multiple populations, i.e., reaching a high sensitivity (>90\%) while avoiding exclusion of any minority populations. ${ }^{22}$ In the SLSJ population, a founder effect occurred during the settlement of the region, thus diminishing the genetic diversity of its population; this effect is well illustrated for the CF population. ${ }^{31}$ Moreover, the SLSJ region is characterized by a low immigration rate; according to the 2001 census of the Quebec population made by the "Instituts de la statistique du Québec," immigrants represent only $0.73 \%$ of the population $\left(2,040 / 278,279\right.$ individuals). ${ }^{32}$ Finally, because there are few rare CF mutations in the SLSJ region, researchers have identified almost all the patients with CFTR mutations.

Table 1 gives phenotypic data about the subjects of the four regions studied. The mean age and body mass index $\left(\mathrm{kg} / \mathrm{m}^{2}\right)$ are similar for the four groups of children and adults who live in those regions. The only difference observed is for the $\mathrm{FEV}_{1}$ (\% pred), which is lower for the children and adults 


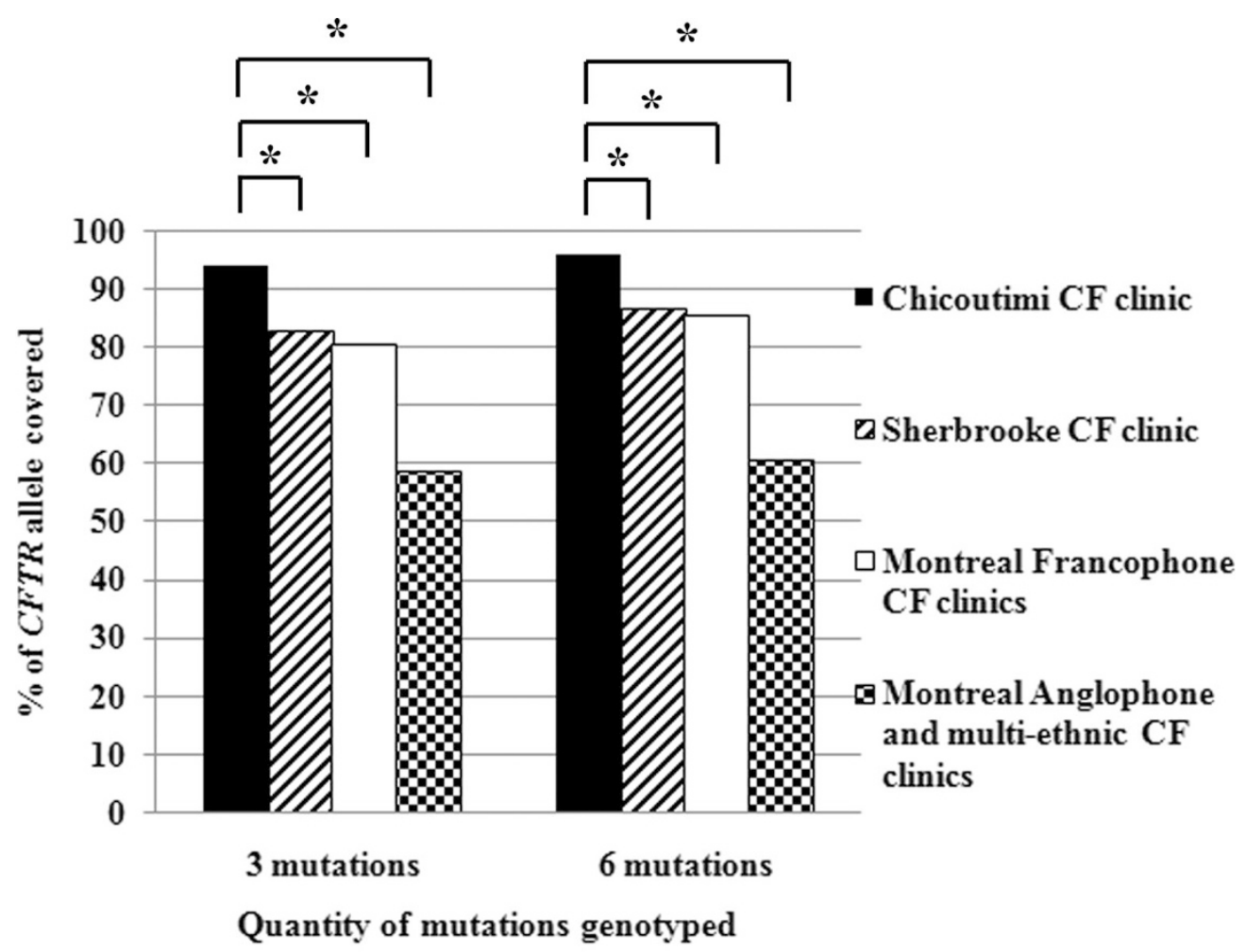

* p-value $<0.0001$

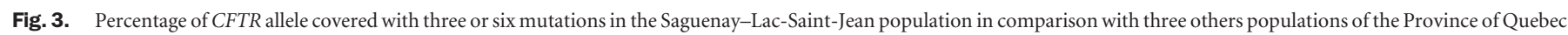

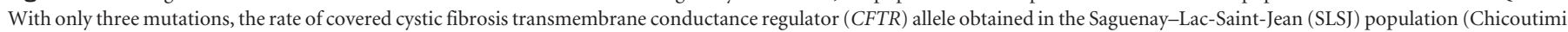

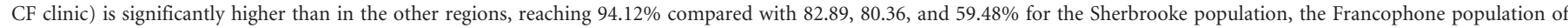

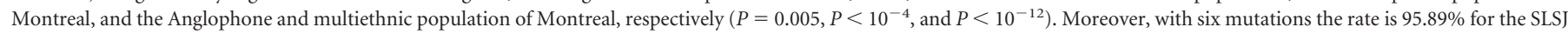
region, also significantly higher than $86.85,85.27$, and $61.18 \%$ for the other ones $\left(P=0.010, P<10^{-3}\right.$, and $P<10^{-13}$, respectively).

from the Anglophone and multiethnic population of Montreal than for subjects of Francophone populations studied. As observed in the data from the Canadian Consortium for Cystic Fibrosis Genetic Studies (Figs. 2 and 3), the distribution of CFTR mutations in SLSJ region is different from that in other regions in the PQ. In the study of Rozen et al., ${ }^{33}$ the authors also observed that the frequency for $\triangle$ F508 mutation was lower in SLSJ region $(58.0 \%)$ than in the other regions of the PQ $(71 \%)(P=0.047)$, and that subjects from the SLSJ region also have a higher $621+1 \mathrm{G}>\mathrm{T}(23.2 \%)$ frequency than those of the remaining regions of the PQ $(12.84 \%)\left(P=10^{-5}\right) .^{21,33}$

Four of our six most frequent mutations $(\triangle \mathrm{F} 508,621+$ $1 \mathrm{G}>\mathrm{T}, \mathrm{A} 455 \mathrm{E}$, and $711+1 \mathrm{G}>\mathrm{T}$ ) are present in the ACMGACOG panel of 23 mutations, representing a detection rate of $94.71 \%$ in the SLSJ population. However, according to our results, a multimutation panel for carrier screening in the SLSJ region could include only the three principal mutations $(\triangle \mathrm{F} 508,621+1 \mathrm{G}>\mathrm{T}$, and $\mathrm{A} 455 \mathrm{E})$, covering a total of $94.12 \%$ of the CFTR alleles present in the SLSJ region (Fig. 3). Another possibility is to include the three additional mutations that are at least present in three different families $(711+1 \mathrm{G}>\mathrm{T}$, 3199del6, and Y1092X), reaching a detection rate of the CFTR alleles of $95.89 \%$ (Fig. 3). These two possibilities are greater than the 90\% sensitivity threshold accepted for screening tests and would be at a low cost. ${ }^{22}$ The implementation of a CF carrier screening program could diminish the incidence of $\mathrm{CF}$ in the SLSJ region and, more importantly, allow future parents to make informed decisions about family planning.

\section{ACKNOWLEDGMENTS}

A.-M. Madore is supported by the Canadian Institutes of Health Research (CIHR). R. Dorfman is supported by the joint Fellowship of CIHR and Ontario Women's Health Council. C. Taylor is supported by the CIHR-University of Toronto Collaborative Graduate Training Program in Molecular Medicine Studentship. C. Laprise is the chairholder of the Canada Research Chair for genetic determinants in asthma (www.chairs. gc.ca). This project was supported by Genome Canada through the Ontario Genomics Institute (no. 2004-OGI-3-05) and the Canadian Cystic Fibrosis Foundation, and donations from the Lloyd Carr-Harris Foundation. The authors express their gratitude to all patients with CF and their families for participating in the study. The authors acknowledge the individual members of The Canadian Consortium for CF Genetic Studies for submission of patient data and sending blood samples from patients with CF and their families. 


\section{References}

1. Charbonneau H, Desjardins B, Légaré J, Denis H. The population of the St. Lawrence Valley, 1608-1760. In: A population history of North America. Cambridge: Cambridge University Press, 2000:99-142.

2. De Braekeleer M, Dao TN. Hereditary disorders in the French Canadian population of Quebec. I. In search of founders. Hum Biol 1994;66:205-223.

3. Harris RC, Matthews G. Historical atlas of Canada. I. From the beginning to 1800 Toronto: University of Toronto Press, 1987.

4. Charbonneau H, Desjardins B, Guillemette A, Landry Y, et al. Naissance d'une population. Les Français établis au Canada au XVIIe siècle. Travaux et documents, Vol. 118. Paris et Montréal: Presses Universitaires de France et Les Presses de l'Université de Montréal, 1987:232.

5. Laberge AM, Michaud J, Richter A, Lemyre E, et al. Population history and its impact on medical genetics in Quebec. Clin Genet 2005;68:287-301.

6. De Braekeleer M. Hereditary disorders in Saguenay-Lac-St-Jean (Quebec, Canada). Hum Hered 1991;41:141-146.

7. De Braekeleer M. Inbreeding, kinship and surnames in hereditary disorders: the experience in Saguenay Lac-Saint-Jean (Quebec). Coll Antropol 1995;19:289-304.

8. Daigneault J, Aubin G, Simard F, De Braekeleer M. Genetic epidemiology of cystic fibrosis in Saguenay-Lac-St-Jean (Quebec, Canada). Clin Genet 1991;40:298-303.

9. Daigneault J, Aubin G, Simard F, De Braekeleer M. Incidence of cystic fibrosis in Saguenay-Lac-St-Jean (Quebec, Canada). Hum Biol 1992;64:115-119.

10. Rowntree RK, Harris A. The phenotypic consequences of CFTR mutations. Ann Hum Genet 2003;67(Pt 5):471-485.

11. Ratjen F, Doring G. Cystic fibrosis. Lancet 2003;361:681-689.

12. de Gracia J, Mata F, Alvarez A, Casals T, et al. Genotype-phenotype correlation for pulmonary function in cystic fibrosis. Thorax 2005;60:558-563.

13. Correlation between genotype and phenotype in patients with cystic fibrosis. The Cystic Fibrosis Genotype-Phenotype Consortium. N Engl J Med 1993;329:1308-1313.

14. Chillon M, Casals T, Mercier B, Bassas L, et al. Mutations in the cystic fibrosis gene in patients with congenital absence of the vas deferens. N Engl J Med 1995;332:1475-1480.

15. Dorfman R, Zielenski J. Genotype/phenotype correlations. In: Bush A, Alton E, Davies J, Griesenbach U, editors. Cystic fibrosis in the 21st Century. Progress in respiratory research. Basel: S. Karger AG, 2006:61-68.

16. Cystic Fibrosis Mutation Database. The cystic fibrosis genetic analysis mutation consortium. Available at: www.genet.sickkids.on.ca/cftr/.

17. Riordan JR, Rommens JM, Kerem B, Alon N, et al. Identification of the cystic fibrosis gene: cloning and characterization of complementary DNA. Science 1989; 245:1066-1073.

18. Kerem B, Rommens JM, Buchanan JA, Markiewicz D, et al. Identification of the cystic fibrosis gene: genetic analysis. Science 1989;245:1073-1080.

19. Zielenski J, Fujiwara TM, Markiewicz D, Paradis AJ, et al. Identification of the
M1101K mutation in the cystic fibrosis transmembrane conductance regulator (CFTR) gene and complete detection of cystic fibrosis mutations in the Hutterite population. Am J Hum Genet 1993;52:609-615.

20. Jentsch TJ, Stein V, Weinreich F, Zdebik AA. Molecular structure and physiological function of chloride channels. Physiol Rev 2002;82:503-568.

21. Bobadilla JL, Macek M Jr, Fine JP, Farrell PM. Cystic fibrosis: a worldwide analysis of CFTR mutations - correlation with incidence data and application to screening. Hum Mutat 2002;19:575-606.

22. Genetic testing for cystic fibrosis. NIH Consens Statement 1997;15:1-37.

23. Zielenski J, Aznarez I, Onay T, Tzounzouris J, et al. CFTR mutation detection by multiplex heteroduplex (mHET) analysis on MDE gel. Methods Mol Med 2002;70:3-19.

24. Krypuy M, Ahmed AA, Etemadmoghadam D, Hyland SJ, et al. High resolution melting for mutation scanning of TP53 exons 5-8. BMC Cancer 2007;7:168.

25. Audrezet MP, Chen JM, Raguenes O, Chuzhanova N, et al. Genomic rearrangements in the CFTR gene: extensive allelic heterogeneity and diverse mutational mechanisms. Hum Mutat 2004;23:343-357.

26. Ferec C, Casals T, Chuzhanova N, Macek M Jr, et al. Gross genomic rearrangement involving deletions in the CFTR gene: characterization of six new events from a large cohort of hitherto unidentified cystic fibrosis chromosomes and meta-analysis of the underlying mechanisms. Eur J Hum Genet 2006;14:567-576.

27. Hantash FM, Milunsky A, Wang Z, Anderson B, et al. A large deletion in the CFTR gene in CBAVD. Genet Med 2006;8:93-95.

28. Hantash FM, Redman JB, Starn K, Anderson B, et al. Novel and recurrent rearrangements in the CFTR gene: clinical and laboratory implications for cystic fibrosis screening. Hum Genet 2006;119:126-136.

29. Grody WW, Cutting GR, Klinger KW, Richards CS, et al. Laboratory standards and guidelines for population-based cystic fibrosis carrier screening. Genet Med 2001;3: $149-154$

30. Watson MS, Cutting GR, Desnick RJ, Driscoll DA, et al. Cystic fibrosis population carrier screening: 2004 revision of American College of Medical Genetics mutation panel. Genet Med 2004;6:387-391.

31. De Braekeleer M, Daigneault J, Allard C, Simard F, et al. Genealogy and geographical distribution of CFTR mutations in Saguenay Lac-Saint-Jean (Quebec, Canada). Ann Hum Biol 1996;23:345-352.

32. Instituts de la statistique du Québec. Recensement de la population 2001 SaguenayLac-Saint-Jean (02). 2001. Available at: http://www.stat.gouv.qc.ca/regions/recens2001 02/02_index.htm\#population.

33. Rozen R, De Braekeleer M, Daigneault J, Ferreira-Rajabi L, et al. Cystic fibrosis mutations in French Canadians: three CFTR mutations are relatively frequent in a Quebec population with an elevated incidence of cystic fibrosis. Am J Med Genet 1992;42: 360-364. 